\title{
EFEKTIVITAS WILAYAH RAMAH ANAK DI KELURAHAN KUNINGAN, SEMARANG UTARA, KAITANNYA DENGAN TINGKAT KRIMINALITAS YANG DILAKUKAN ANAK
}

\author{
Muhammad Iftar Aryaputra
}

Fakultas Hukum, Universitas Semarang,

\author{
Dewi Tuti Muryati
}

Fakultas Hukum, Universitas Semarang,

\author{
Agus Saiful Abib
}

Fakulktas Hukum, Universitas Semarang,

\begin{abstract}
Abstrak
Upaya perlindungan anak menjadi hal yang sangat penting. Salah satu upaya yang dilakukan terkait hal ini adalah membentuk wilayah ramah anak. Di Kota Semarang, wilayah ramah anak diterapkan di Kelurahan Kuningan. Pembentukan wilayah ramah anak berangkat dari keprihatinan terhadap kurangnya fasilitas berupa sarana dan prasarana bermain bagi anak. Permasalahan yang diangkat dalam penelitian ini yaitu, (1) bagaimana model wilayah ramah anak yang terdapat di kelurahan Kuningan?; (2) bagaimana kaitan antara pembentukan wilayah ramah anak dengan kriminalitas yang dilakukan anak?. Penelitian ini merupakan penelitian hukum sosiologis. Dengan demikian, data yang digunakan adalah data primer yang ditunjang dengan data sekunder yang selanjutnya dianalisis secara kualitatif. Berdasarkan hasil penelitian didapatkan hasil, pertama, wilayah ramah anak di Kelurahan Kuningan pada dasarnya lebih menonjolkan perubahan secara fisik, terutama dalam hal fasilitas bermain dan belajar anak. Selain itu, ada beberapa fasilitas non fisik lainnya sebagai penunjang fasilitas fisik yang telah ada. Kedua, wilayah ramah anak di Kelurahan Kuningan pada dasarnya tidak dibentuk untuk mengurangi kriminalitas anak di walayah tersebut. Namun demikian, secara tidak langsung, wilayah ramah anak dapat menjadi pemutus mata rantai kenakalan anak dengan membentuk generasi baru yang terhindar dari hal-hal yang berhubungan dengan kriminalitas.
\end{abstract}

\begin{abstract}
Child protection efforts become very important. One of the efforts made in this regard is to establish "wilayah ramah anak". In Kota Semarang, "wilayah ramah anak" is implemented in Kelurahan Kuningan. It is hoped that this effort will not only be a way to provide protection to children but also to prevent children from doing things that are against the norm. Issues raised in this study are, (1) how the model of "wilayah ramah anak" contained in Kelurahan Kuningan?; (2) what is the correlation between the establishment of "wilayah ramah anak" with the crime committed by children ?. This research is a sociological law research. Thus, the data used are primary data supported by secondary data which then analyzed qualitatively. Based on the results of research obtained results, first, child-friendly areas in Kelurahan Kuningan basically more physical changes, especially in terms of play facilities and learning children. In addition, there are several other non-physical facilities to support existing physical facilities. Second, "wilayah ramah anak" in Kelurahan Kuningan basically not formed to reduce the crime of children in the walayah. However, indirectly, child-friendly territory can be the breaker of a child's delinquency chain by forming a new generation that avoids crime-related matters.
\end{abstract}




\section{A. Pendahuluan}

Usia anak memiliki tingkat kerentanan terhadap kriminalitas. Anak bisa dengan mudah menjadi korban tindak pidana atau justru menjadi pelaku tindak pidana. Berkaitan dengan hal ini, anak harus mendapatkan perhatian dari segenap pihak. Banyaknya angka kriminalitas yang dilakukan anak dan anak yang menjadi korban tindak pidana, mengindikasikan bahwa masalah anak perlu mendapatkan perhatian yang serius.

Berdasarkan data yang diperoleh dari Komisi Perlindungan Anak Indonesia (KPAI), jumlah kasus anak pelaku tindak pidana (dari berbagai katagori tindak pidana) berjumlah 3250 yang terjadi dalam rentang waktu tahun 2011-2016. Dari data tersebut, jumlah anak pelaku kekerasan seksual (pemerkosaan, pencabulan, sodomi, pedofilia) menempati jumlah tertinggi dengan 1498 kasus atau 46\% dari jumlah keseluruhan tindak pidana. ${ }^{1}$ Sedangkan data kasus anak yang menjadi korban, berdasarkan data KPAI dalam kurun waktu tahun 2011-2016, jumlah anak korban terbanyak adalah anak korban kekerasan seksual dengan jumlah 1965 kasus. $^{2}$

Dengan demikian, dapat disimpulkan masih banyak jumlah anak yang menjadi pelaku tindak pidana dan menjadi korban tindak pidana. Upaya perlindungan terhadap anak, jangan hanya dimaknai sebagai upaya menghindarkan anak menjadi korban tindak pidana, melainkan harus dimaknai pula sebagai suatu upaya menghindarkan anak sebagai pelaku tindak pidana. Ditinjau dari sudut normatif, masalah perlindungan anak pertama kali diformulasikan dalam UU No. 23 Tahun 2002 tentang Perlindungan Anak. Selanjutnya, UU No. 23 Tahun 2002

1 "Rincian Data Kasus Berdasarkan Klaster Perlindungan Anak, 2011-2016 | Bank Data Perlindungan Anak," diakses 11 Maret 2018, http://bankdata.kpai.go.id/tabulasi-data/data-kasus-pertahun/rincian-data-kasus-berdasarkan-klasterperlindungan-anak-2011-2016.

${ }^{2}$ Ibid. mengalami perubahan untuk yang pertama kali melalui UU No. 35 Tahun 2014 tentang Perubahan Atas UU No. 23 Tahun 2002 tentang Perlindungan Anak. Pada tahun 2016, UU No. 23 Tahun 2002 mengalami perubahan yang kedua, melalui Perppu No. 1 Tahun 2016 yang kemudian ditetapkan menjadi undang-undang berdasarkan UU No. 17 Tahun 2016.

Salah satu upaya perlindungan terhadap anak, telah dilakukan oleh Kelurahan Kuningan, Kecamatan Semarang Utara dengan membentuk wilayah ramah anak. Menurut Hendrar Prihadi, Walikota Semarang, latar belakang didirikannya wilayah ramah anak dikarenakan di Semarang belum ada tempat yang mampu memberikan akomodiasi bagi anak-anak untuk melakukan aktivitas sosial seperti bermain, belajar, berkumpul dengan teman sebaya. Ditambahkan oleh Prihadi, gadget membuat anak-anak kehilangan waktu bermain dengan teman sebayanya, sehingga diperlukan tempat khusus yang dapat digunakan untuk bermain dan berkumpul bersama kedua orangtuanya maupun teman sebaya. $^{3}$

Pembentukan wilayah ramah anak juga harus memiliki beberapa peran sekaligus, pertama harus mampu menjadi wilayah yang mampu memenuhi kebutuhan bermain maupun edukasi anak; kedua harus mampu menghindarkan anak dari korban tindak pidana; ketiga harus mampu menghindarkan anak menjadi pelaku tindak pidana. Dengan demikian, pembentukan Wilayah ramah anak diharapkan dapat menjadi bagian integral dari upaya perlindungan anak. Upaya perlindungan terhadap anak, bukan hanya diartikan sebagai suatu usaha dalam menghindarkan anak menjadi korban tindak pidana melainkan juga harus mampu

\footnotetext{
3 "Kelurahan Kuningan Semarang Utara Kini Jadi Kota Ramah Anak," diakses 11 Maret 2018, http://semarangkota.go.id/berita/read/7/beritakota/1665/kelurahan-kuningan-semarang-utara-kini-jadikota-ramah-anak.
} 
menghindarkan anak menjadi pelaku tindak pidana. Dilihat dari sudut kebijakan sosial (social policy), upaya perlindungan anak pada dasarnya merupakan bagian dari upaya perlindungan masyarakat (social defence). Hal ini penting dilakukan, mengingat anak adalah generasi penerus yang harus dihindarkan dari kriminalitas, baik seabgai korban ataupun pelaku.

Berdasarkan pengamatan awal yang peneliti di kelurahan Kuningan, didapatkan fakta bahwa tingkat kenakalan anak yang terjadi di wilayah tersebut tergolong tinggi. Para pelaku rata-rata masih bersekolah di tingkat SD dan SMP. Beberapa bentuk yang sering dilakukan anak yaitu tawuran, minum-minuman keras, ngelem. Dengan demikian dapat disimpulkan bahwa kelurahan Kuningan memiliki tingkat kenakalan anak yang tinggi. Tingginya tingkat kenakalan anak di wilayah tersebut, mendorong tokoh masyarakat di kelurahan Kuningan untuk menciptakan suatu kondisi lingkungan yang mampu mengurangi tingkat kenakalan yang dilakukan anak, melalui pembentukan wilayah ramah anak.

Menarik untuk dikaji lebih lanjut, mengenai pembentukan wilayah ramah anak di kelurahan Kuningan sebagai suatu bentuk perlindungan bagi anak. Penelitian ini lebih terfokus dalam mengkaji efektivitas wilayah ramah anak yang dikaitkan dengan tingkat kenakalan/kriminalitas yang dilakukan anak. Dengan demikian, permasalahan yang akan dikaji dalam penelitian ini dapat dituliskan sebagai berikut:

1. Bagaimana model wilayah ramah anak yang terdapat di kelurahan Kuningan, Kecamatan Semarang Utara?

2. Bagaimana kaitan antara pembentukan wilayah ramah anak dengan kriminalitas yang dilakukan anak?

Dari rumusan masalah di atas, maka tujuan penelitian dapat dituliskan sebagai berikut:

1. Mengetahui model wilayah ramah anak yang terdapat di kelurahan Kuningan, Kecamatan Semarang Utara;
2. Mengetahui dan menganalisis kaitan antara pembentukan wilayah ramah anak dengan kriminalitas yang dilakukan anak.

Penelitian ini merupakan penelitian hukum sosiologis, atau yang sering dikenal dengan penelitian yuridis sosiologis. Penelitian yuridis sosiologis menurut Menurut Ronny Hanitijo Soemitro, diartikan sebagai penelitian yang mempelajari dan meneliti hubungan timbal balik antara hukum dengan lembagalembaga sosial yang lain, dimana hukum tidak dikonsepsikan sebagai suatu gejala normatif yang mandiri, melainkan dikaitkan secara nyata dengan variabel-variabel sosial yang lain. ${ }^{4}$ Sedangkan menurut Fajar dan Achmad, penelitian yuridis sosiologis adalah penelitian hukum yang berbasis pada ilmu hukum normatif, namun tidak melakukan pengkajian terhadap sistem norma dalam peraturan perundangundangan, melainkan melakukan pengkajian terhadap bagaimana reaksi dan interaksi yang terjadi ketika suatu sistem norma dalam suatu perundang-undangan bekerja dalam masyarakat. $^{5}$

Dikarenakan penelitian ini adalah penelitian yuridis sosiologis, maka data primer menjadi data utama. Data primer diperoleh dengan melakukan observasi dan wawancara kepada aparat kelurahan dan warga masyarakat di Kelurahan Kuningan. Data primer didukung dengan data sekunder. Dalam penelitian ini, data sekunder yang digunakan adalah bahan hukum primer yang berasal dari perundangundangan bahan hukum sekunder berupa buku, jurnal ilmiah, maupun artikel internet. Data yang diperoleh selanjutnya dianalisis berdasar analisis kualitatif.

4 Ronny Hanitijo Soemitro, Metode penelitian hukum dan jurimetri (Jakarta, Indonesia: Ghalia, 1990), 34.

5 Mukti Fajar dan Yulianto Achmad, Dualisme penelitian hukum normatif dan empiris (Yogjakarta: Pustaka Pelajar, 2010), 47. 


\section{B. Model Wilayah Ramah Anak di Kelurahan Kuningan, Kecamatan Semarang Utara \\ Data menunjukkan bahwa} sepanjang tahun 2011 sampai dengan 2016, terdapat 4.405 anak yang menjadi korban tindak pidana. Kriteria anak korban bisa meliputi beberapa kriteria, diantaranya anak korban kekerasan seksual, fisik, psikis, pembunuhan, kecelakaan lalu lintas (laka lantas). Dari jumlah tersebut, 1.965 adalah anak korban kekerasan seksual, disusul dengan anak korban kekerasan fisik yang mencapai 920 anak korban. ${ }^{6}$

Selain banyaknya jumlah anak korban, yang tidak kalah penting untuk diperhatikan adalah anak sebagai pelaku tindak pidana. Berdasarkan data yang dimiliki KPAI, dalam kurun waktu tahun 2011 sampai dengan 2016, terdapat 3.250 jumlah anak yang melakukan kriminalitas, misalnya berupa kekerasan fisik, psikis, seksual, pembunuhan, pencurian. Dari keseluruhan jumlah tersebut, menurut KPAI, 1.498 anak menjadi pelaku kekerasan seksual, disusul dengan anak pelaku kekerasan fisik sejumlah 423 anak. $^{7}$

Melihat realitas di atas, sebenarnya permasalahan utama terkait anak, bukan hanya anak sebagai pelaku kriminalitas, melainkan juga anak sebagai kepada korban kriminalitas. Kedua masalah ini harus mendapat perhatian khusus dari pemerintah. Upaya pemerintah yang harus dilakukan terkait anak, yaitu mampu menjauhkan anak menjadi pelaku kriminalitas sekaligus menghindarkan anak menjadi korban kriminalitas. Salah satu upaya tersebut dapat diwujudkan dengan jalan membentuk wilayah ramah anak. Upaya pembentukan wilayah ramah anak ini, telah dilakukan oleh Pemerintah Kota Semarang. Project wilayah ramah anak di Kota Semarang, untuk pertama

6 "Rincian Data Kasus Berdasarkan Klaster Perlindungan Anak, 2011-2016 | Bank Data Perlindungan Anak."

${ }^{7}$ Ibid. kalinya diterapkan pada Kelurahan Kuningan, Semarang Utara.

Kelurahan Kuningan merupakan salah satu wilayah kelurahan di Kecamatan Semarang Utara. Kelurahan Kuningan memiliki luas wilayah 14.515 Ha. Kelurahan Kuningan berbatasan dengan Kelurahan Bandarharjo (batas utara dan timur), Kelurahan Dadapsari (batas selatan), dan Kelurahan Penggung Lor (batas barat). Secara administrasi, Kelurahan Kuningan dibagi menjadi 11 RW dan 87 RT, dengan jumlah penduduk pada tahun 2017 sebanyak 14.529 jiwa, dengan 3.769 kepala keluarga (KK).

Project wilayah ramah anak di Semarang, merupakan salah satu upaya yang dilakukan oleh Pemerintah Kota Semarang dalam memberikan perlindungan terhadap tumbuh kembang anak. Menurut Joko Sumarno, Lurah Kelurahan Kuningan, pembentukan wilayah ramah anak di Kelurahan Kuningan dilatar belakangi karena di wilayah tersebut banyak sekali terdapat bayi, balita, dan anak-anak terutama di wilayah RT IX, di sisi lain fasilitas untuk tumbuh kembang anak tidak memadai. ${ }^{8}$

Kelurahan Kuningan sebelumnya dikenal sebagai suatu wilayah yang kumuh dan padat penduduk. Selain itu, wilayah ini dikenal juga dengan wilayah yang tidak ramah bagi anak. Kenakalankenakalan anak hampir setiap hari terjadi di wilayah tersebut. Menurut Joko Sumarno, beberapa bentuk kenakalan anak yang sering dilakukan adalah ngelem, minum-minuman keras, tawuran, bahkan tidak jarang menggunakan obatobatan terlarang. ${ }^{9}$ Hal ini juga ditegaskan oleh Tijanto DM, Kepala Seksi Pemerintahan dan Pembangunan, yang menyatakan bahwa Kelurahan Kunigan banyak terdapat anak-anak, namun sebelum dibentuknya wilayah ramah anak, Kelurahan Kuningan terkenal dengan suatu kampung yang gelap, kumuh, dan

\footnotetext{
${ }^{8}$ Joko Sumarno, 23 November 2017.

${ }^{9}$ Ibid.
} 
http://journals.usm.ac.id/index.php/jdsb

fasilitas bermain bagi anak sangat minim. $^{10}$ Dengan demikian, dalam pembentukan wilayah Kelurahan Kuningan menjadi wilayah ramah anak, ada suatu upaya dari aparat setempat untuk mengubah stigma/citra negatif menjadi stigma positif dan konstruktif.

Berdasarkan hasil wawancara yang tim lakukan, pembentukan wilayah ramah anak di Kelurahan Kuningan secara sosiologis memang didasarkan pada keadaan wilayah Kelurahan Kuningan yang dikenal sebagai wilayah yang kumuh dan tidak ramah bagi anak. Keadaan ini kemudian menjadi salah satu perhatian dari Pemerintah Kota Semarang. Selanjutnya, Wakil Walikota Semarang mewacanakan pembentukan wilayah ramah anak di wilayah Kuningan. Berdasar hal ini, kemudian para perangkat kelurahan disertai dengan warga setempat, menindaklanjuti keinginan dari Wakil Walikota Semarang. ${ }^{11}$

Keinginan dari Pemerintah Kota Semarang terkait pembentukan wilayah ramah anak di Kelurahan Kuningan, mendapatkan reaksi positif dari perangkat kelurahan dan warga setempat. Hal ini dikarenakan warga Kelurahan Kuningan ingin menghapus stigma/citra buruk dari kelurahan mereka. Terlebih lagi, mengingat jumlah anak-anak di wilayah tersebut cukup banyak, timbul suatu kesadaran dari para warga setempat untuk memberikan pelayanan terbaik bagi anakanak mereka, sehingga anak-anak di Kelurahan Kuningan bisa berkembang dengan baik.

Menurut Joko Sumarno, project wilayah ramah anak di Kelurahan Kuningan, dimulai di RW IX. Pemilihan RW IX sebagai project wilayah ramah anak dikarenakan jumlah anak-anak terbanyak di Kelurahan Kuningan ada pada RW tersebut. Project wilayah ramah anak di RW IX sudah berjalan sejak tahun 2016 hingga sekarang. ${ }^{12}$ Pembangunan

\footnotetext{
${ }^{10}$ Trijanto, wawancara, 28 November 2017.

${ }^{11}$ Ibid.

${ }^{12}$ Sumarno, wawancara. 23 November 2017.
}

wilayah ramah anak di Kelurahan Kuningan dimulai dengan pembangunan yang sifatnya fisik, seperti penataan lingkungan, pembuatan taman, dan pengecatan lingkungan dengan cat beraneka warna.

Selain pembuatan taman dan pengecatan kampung dengan warna "pelangi", dapat dituliskan beberapa fasilitas fisik lain yang terdapat di wilayah ramah anak kelurahan kuningan seperti taman bacaan anak dan bank sampah yang digunakan dalam melakukan pengelolaan sampah masyarakat. Selain fasilitas yang bersifat fisik, aparat kelurahan juga menyediakan fasilitas yang sifatnya non fisik, seperti latihan bela diri, senam, car free day, serta membuat jaringan perlindungan anak yang diprakarsai atas kerjasama Kelurahan Kuningan dengan stake holder terkait.

Selain fasilitas-fasilitas sebagaimana telah diuraikan sebelumnya, aparat kelurahan juga melakukan tindakan persuasif kepada para warganya, terutama para orangtua. Tindakan ini dilakukan agar program wilayah ramah anak dapat mendapatkan tujuannya, yaitu agar wilayah Kuningan menjadi wilayah yang nyaman dan membahagiakan bagi anak serta menjadi wilayah yang sarat dengan nilai-nilai edukasi. Salah satu tindakan yang dilakukan oleh aparat kelurahan yaitu melakukan sosialisai kepada orangtua untuk menggalakkan jam wajib belajar. Bahkan hal ini dituangkan secara resmi melalui SK Lurah Kuningan Nomor 401/26/2016. Dalam SK tersebut, dinyataan bahwa pukul 18.30-20.30 merupakan jam wajib belajar. Oleh karena itu, semua orangtua wajib untuk mematikan televisi dengan tujuan agar anak dapat memulai aktifitas belajar maupun mengaji. Himbauan tersebut pada dasarnya bersifat persuasif. Artinya, dalam implementasinya, masih banyak orangtua yang tidak mengindahkan himbauan tersebut. Menurut Joko Sumarno, apabila dihitung prosentasenya, 
hanya sekitar $10 \%$ orangtua yang peduli dengan himbauan tersebut. ${ }^{13}$

Berdasarkan uraian-uraian tentang wilayah ramah anak di Kelurahan Kuningan Semarang Utara, apabila kita kaitkan dengan aspek yuridis, maka pembentukan wilayah ramah anak pada dasarnya merupakan bagian dari perlindungan terhadap anak. Masalah perlindungan anak, saat ini sudah diformulasikan dalam UU No. 23 Tahun 2002 tentang Perlindungan Anak yang telah diubah dengan UU No. 35 Tahun 2014 dan UU No. 17 Tahun 2016 Jo. Perppu No. 1 Tahun 2016 (selanjutnya ditulis UU Perlindungan Anak)

Dalam konsideran UU No. 23 Tahun 2002, dijelaskan bahwa negara menjamin kesejahteraan tiap-tiap warga negaranya, termasuk memberikan perlindungan terhadap anak. Anak adalah amanah dan karunia Tuhan Yang Maha Esa, yang dalam dirinya melekat harkat dan martabat sebagai manusia seutuhnya. Anak merupakan tunas, potensi, dan generasi muda penerus cita-cita perjuangan bangsa, memiliki peran strategis dan mempunyai ciri dan sifat khusus yang menjamin kelangsungan eksistensi bangsa dan negara pada masa depan. Oleh karena itu, agar setiap anak kelak mampu memikul tanggung jawab tersebut, maka ia perlu mendapat kesempatan yang seluas-luasnya untuk tumbuh dan berkembang secara optimal, baik fisik, mental maupun sosial, dan berakhlak mulia, perlu dilakukan upaya perlindungan serta untuk mewujudkan kesejahteraan anak dengan memberikan jaminan terhadap pemenuhan hak-haknya serta adanya perlakuan tanpa diskriminasi. Kata kunci dari konsideran tersebut adalah perlindungan anak.

Dalam UU Perlindungan Anak, Perlindungan Anak diartikan sebagai segala kegiatan untuk menjamin dan melindungi anak dan hak-haknya agar dapat hidup, tumbuh, berkembang, dan

${ }^{13}$ Ibid. berpartisipasi secara optimal sesuai dengan harkat dan martabat kemanusiaan, serta mendapat perlindungan dari kekerasan dan diskriminasi. Dari definisi tersebut, dapat kita simpulkan bahwa upaya perlindungan anak tidak hanya ditujukan terhadap anak itu sendiri melainkan juga ditujukan terhadap hakhak yang melekat pada anak. Konsep perlindungan anak harus dilakukan secara utuh, menyeluruh, dan komprehensif. Apabila dikaitkan dengan ketentuan tersebut, maka pembentukan wilayah ramah anak di Kelurahan Kuningan dapat dikatagorikan sebagai upaya perlindungan anak, khususnya dalam menjamin hak-hak anak, yaitu hak memanfaatkan waktu luang, bergaul dengan anak yang sebaya, bermain, berekreasi, dan berkreasi sesuai dengan minat, bakat, dan tingkat kecerdasannya demi pengembangan diri.

Tujuan dari upaya perlindungan anak menurut Pasal 3 UU Perlindungan Anak, yaitu menjamin terpenuhinya hakhak anak agar dapat hidup, tumbuh, berkembang, dan berpartisipasi secara optimal sesuai dengan harkat dan martabat kemanusiaan, serta mendapat perlindungan dari kekerasan dan diskriminasi, demi terwujudnya anak Indonesia yang berkualitas, berakhlak mulia, dan sejahtera. Melihat dari redaksi Pasal 3 tersebut, tegas bahwa dalam tumbuh kembangnya, anak harus mendapatkan perlindungan dari kekerasan dan diskriminasi.

Bentuk-bentuk kekerasan yang dimaksud oleh UU Perlindungan Anak dapat dituliskan sebagai berikut:

1. Diskriminasi, penelentaran terhadap anak;

2. Mengetahui seorang anak dalam keadaan berbahaya (mis: berhadapan dengan hukum, anak dari kelompok minoritas dan terisolasi, anak yang tereksploitasi secara ekonomi dan/atau seksual, anak yang diperdagangkan, anak yang menjadi korban penyalahgunaan narkotika, dll) dan tidak melakukan pertolongan; 
3. Melakukan kekejaman, kekerasan atau ancaman kekerasan, atau penganiayaan;

4. Dengan tipu muslihat, kebohongan, membujuk, kekerasan atau ancaman, memaksa melakukan persetubuhan;

5. Dengan tipu muslihat, kebohongan, membujuk, kekerasan atau ancaman, untuk melakukan atau membiarkan dilakukan perbuatan cabul;

6. Memperdagangkan, menjual, atau menculik;

7. Mengeksploitasi ekonomi atau seksual anak dengan maksud untuk menguntungkan diri sendiri atau orang lain.

Berdasarkan Pasal 20 UU Perlindungan Anak, perlindungan anak menjadi kewajiban dan tanggungjawab dari semua pihak, yaitu negara, pemerintah, masyarakat, keluarga, dan orang tua. Dengan demikian, upaya perlindungan anak harus dilakukan oleh berbagai kalangan dengan tujuan menjaga tumbuh kembang anak. Melihat dari redaksi Pasal 20, maka upaya perlindungan anak merupakan tanggung jawab bersama. Dengan demikian, setiap warga masyarakat juga memiliki kewajiban dan tanggung jawab bersama dalam memberikan perlindungan dan menjamin hak-hak anak.

Dalam suatu upaya perlindungan anak, menurut Pasal 22 UU Perlindungan Anak, ada suatu kewajiban dari negara dan pemerintah untuk memberikan dukungan sarana dan prasarana dalam penyelenggaraan perlindungan anak. Apabila hal ini kita kaitkan dengan pembentukan wilayah ramah anak di Kelurahan Kuningan, maka hal ini merupakan implementasi Pasal 22 UU Perlindungan Anak. Dalam hal ini, Pemerintah Kota Semarang bersama aparat kelurahan, memberikan dukungan berupa sarana dan prasarana dalam pembentukan wilayah ramah anak. Dengan demikian, dalam hal ini Pemerintah Kota Semarang dan pihak Kelurahan Kuningan telah menjalankan perannya dalam upaya perlindungan anak. Dengan kata lain, Pemerintah Kota Semarang melalui kantor Kelurahan Kuningan memberikan perhatian khusus dalam perlindungan anak yang diwujudkan dalam pembentukan wilayah ramah anak.

Upaya lain yang dilakukan oleh Kelurahan Kuningan dalam perlindungan anak yaitu dengan menjadi bagian dari Jaringan Perlindungan Anak (JPA). JPA merupakan suatu usaha perlindungan anak yang dilakukan oleh beberapa stake holder terkait, pihak Kelurahan Kuningan, RT dan RW di Kelurahan uningan, LSM Setara, lembaga karang taruna Kelurahan Kuningan, kelompok PKK, serta melibatkan beberapa aparat penegak hukum seperti babinsa, kamtibmas, dan juga melibatkan tokoh-tokoh agama. JPA ini dibentuk khusus menangani kasus-kasus anak yang berkonflik dengan hukum, dalam arti anak yang melakukan tindak pidana. Menurut undang-undang, anak yang bisa dipertanggungjawabkan secara hukum adalah mereka yang berusia 12-18 tahun. Dikarenakan pendekatan yang dianut dalam sistem peradilan pidana anak adalah pendekatan peradilan restoratif, maka sebisa mungkin anak pelaku tindak pidana dihindarkan dari sistem peradilan. Dalam hal ini, disinilah peran dari JPA, agar semaksimal mungkin mengupayakan agar anak pelaku tindak pidana, kasusnya dapat diselesaikan tanpa melalui proses peradilan pidana.

C. Kaitan Pembentukan Wilayah Ramah Anak dengan Tingkat Kriminalitas Anak

Berdasarkan penelitian yang tim lakukan, wilayah ramah anak di Kelurahan Kuningan tidak dibentuk dengan tujuan untuk menekan angka kriminalitas anak di wilayah tersebut. Wilayah ramah anak di Kelurahan Kuningan dibentuk dengan tujuan utama yaitu memenuhi hak-hak anak dalam bermain dan belajar. Dengan demikian, wilayah ramah anak di Kelurahan Kuningan berangkat dari minimnya fasilitas dan ruang bermain bagi anak. 
Sebelum dibentuknya wilayah ramah anak di Kelurahan Kuningan, wilayah tersebut terkenal dengan stigma/citra yang negatif. Hal ini dikarenakan banyak terjadi kriminalitas maupun perilaku-perilaku menyimpang yang dilakukan oleh anggota masyarakatnya, terutama mereka yang masih dikatagorikan sebagai anak, pelajar, maupun remaja. Bahkan tawuran yang sering terjadi, biasanya dilakukan dengan warga Kelurahan Bandarharjo, seolah-olah sudah menjadi kebiasaan yang dilakukan turun temurun. Singkatnya, wilayah Kelurahan Kuningan tadinya adalah wilayah yang memililiki citra buruk.

Perlahan namun pasti, stigma negatif yang dialamatkan kepada wilayah Kelurahan Kuningan, perlahan mulai dihapus dengan hadirnya konsep wilayah ramah anak. Walaupun di awal dituliskan bahwa pembentukan wilayah ramah anak tidak ditujukan untuk menghilangkan kriminalitas (namun lebih kepada pemberian fasilitas kepada anak), secara tidak langsung, pembentukan wilayah ramah anak yang mulai diterapkan di RW IX Kelurahan Kuningan, secara tidak langsung turut menurunkan angka kenakalan yang dilakukan anak di wilayah tersebut. Hal ini juga diakui baik oleh Sumarno dan Trijanto selaku Lurah dan Kepala Seksi Pemerintahan dan Pembangunan. Menurut mereka berdua, kehadiran kampung ramah anak di wilayah Kelurahan Kuningan belum bisa menghapus keseluruhan kenakalan atau kriminalitas anak di wilayah tersebut. Namun demikian, sejak hadirnya wilayah ramah anak, jumlah kenakalan remaja mulai berkurang. Rentang usia anak yang sering melakukan kenakalan yaitu mereka yang beusia 15-17 tahun. Dengan demikian, menurut UU No. 11 Tahun 2012 tentang Sistem Peradilan Pidana, usia tersebut masih dikatagorikan sebagai usia anak, sehingga apabila mereka berhadapan dengan hukum, harus ditangani dengan cara-cara yang khusus.
Ditambahkan oleh Sumarno, sebelum dicanangkan sebagai wilayah ramah anak, setiap malam minggu, banyak remaja yang nongkrong di depan kantor kelurahan minum-minuman keras sambil bermain gitar. Namun sejak wilayah Kelurahan Kuningan dijadikan sebagai project wilayah ramah anak oleh Pemerintah Kota Semarang, frekuensi aktifitas tersebut perlahan mulai berkurang. ${ }^{14}$ Hal ini juga ditegaskan oleh Trijanto yang menyatakan, "dulu setiap malam minggu, kantor kelurahan dijadikan sebagai "markas" untuk mabuk-mabukan. Namun setelah Kelurahan Kuningan ditetapkan sebagai wilayah ramah anak, kami didampingi dengan ketua-ketua RT dan RW, anggota Kepolisian Sektor, dan Koramil, rajin untuk melakukan monitoring hampir setiap malam". ${ }^{15}$ Dengan melakukan "patroli" gabungan, ternyata membawa dampak positif. Hal ini terbukti dengan mulai berkurangnya aktifitas mabuk-mabukan di kantor kelurahan.

Berkaitan dengan tingkat kriminalitas di wilayah Kelurahan Kuningan, sebagaimana telah diuraikan sebelumnya, tingkat kriminalitas yang dilakukan oleh anak memang tidak bisa hilang secara keseluruhan. Namun prosentasenya mulai berkurang. Menurut Sumarno, banyak pengaruh yang menjadi penyebab masih adanya kenakalan anak (bahkan tidak jarang kenakalan tersebut mengarah kepada suatu aktifitas kriminalitas) di wilayahnya. Faktor pertama adalah lingkungan. Lingkungan yang telah terbentuk di wilayah Kuningan sudah terbiasa dengan kenakalan-kenakalan bahkan juga kriminalitas. Secara tidak langsung, hal ini juga turut terekam di memori anak-anak, sehingga sangat sulit untuk menghapus rekaman tersebut. Faktor kedua berkaitan dengan masih rendahnya kesadaran keluarga, terutama orangtua, terhadap aktifitas yang dilakukan anaknya. Di wilayah RW IX yang menjadi wilayah

\footnotetext{
14 Ibid.

${ }^{15}$ Trijanto, wawancara.
} 
percontohan kampung ramah anak, diperkirakan hanya sekitar $10 \%$ orangtua yang peduli dengan aktifitas anak-anaknya. Selebihnya tidak peduli dengan apa yang dilakukan anak-anaknya.

Berdasarkan uraian-uraian di atas, dapat disimpulkan bahwa pembentukan wilayah ramah anak di Kelurahan Kuningan, memang pada awalnya tidak ditujukan untuk menghapuskan angka kriminalitas yang ada di wilayah tersebut. Namun demikian, pembentukan wilayah ramah anak di Kelurahan Kuningan dapat memutus mata rantai kenakalan-kenakalan atau bahkan kriminalitas anak. Dengan terbentuknya generasi baru, diharapkan dapat membentuk citra positif bagi wilayah Kuningan. Namun untuk memutus mata rantai kenakalan/ kriminalitas anak, bukan hal yang mudah. Diperlukan suatu usaha bersama yang saling bersinergi baik antara pemerintah maupun warga masyarakat, termasuk pula stake holder terkait seperti LSM.

Terkait dengan masalah kriminalitas anak yang terjadi di wilayah Kuningan, aparat kelurahan Kuningan memiliki perhatian yang besar kepada anak-anak di wilayahnya yang berhadapan dengan hukum, karena melakukan kriminalitas. Menurut Sumarno, beberapa kenakalan anak yang menjerumus ke arah kriminalitas, yang sering dilakukan, seperti tawuran, pencurian dan mengkonsumsi obat-obat terlarang. ${ }^{16}$ Ditambahkan oleh Sumarno, ketika ada anak di wilayahnya mendapatkan masalah hukum, pihak kelurahan siap untuk mengupayakan agar kasusnya dapat diselesaikan secara kekeluargaan. Namun untuk kasus-kasus yang berat, pihak kelurahan akan menyerahkan sepenuhnya kepada aparat yang berwajib. Apabila kasusnya ringan, seperti pencurian, perkelahian, atau tawuran, pihak kelurahan akan melakukan beberapa upaya agar kasus yang sedang

${ }^{16}$ Sumarno, wawancara. dialami dapat diselesaikan secara damai/kekeluargaan. ${ }^{17}$

Menurut Sumarno, ketika ada anak di wilayah Kuningan yang mengalami masalah hukum, maka tindakan pertama dari kelurahan adalah menyerahkan sepenuhnya kepada pihak kepolisian. Setelah anak berada di kantor polisi, di sini pihak kelurahan berupaya untuk menyelesaikan kasus secara kekeluargaan, dengan harapan agar kasusnya tidak sampai ke pengadilan. Selain ikut mengupayakan penyelesaian perdamaian, pihak kelurahan juga ikut melakukan suatu upaya pemanggilan terhadap orangtua dari anak yang terlibat kasus hukum. ${ }^{18}$

Berdasarkan uraian-uraian di atas, dapat disimpulkan bahwa Kelurahan Kuningan memiliki perhatian yang besar kepada anak, baik anak-anak yang tidak berhadapan dengan hukum ataupun anakanak yang berhadapan dengan hukum. Hal ini dibuktikan dengan keterlibatan aktif dari pihak kelurahan dalam mengupayakan perdamaian dalam tindak pidana yang dilakukan anak dengan korbannya. Dengan demikian, apa yang telah dilakukan Kelurahan Kuningan sejalan dengan paradigma yang terdapat UU No. 11 Tahun 2012 tentang Sistem Peradilan Pidana Anak (selanjutnya ditulis UU SPPA).

Pada dasarnya, UU SPPA berpandangan bahwa anak yang melakukan suatu tindak pidana, sebisa mungkin dijauhkan dari proses peradilan. Dalam UU SPPA, terdapat suatu upaya yang dapat dilakukan oleh aparat penegak hukum dalam menjauhkan anak pelaku tindak pidana dari proses peradilan, yaitu melalui diversi. Menurut Pasal 1 angka 7 UU SPPA, diversi dimaknai sebagai pengalihan penyelesaian perkara Anak dari proses peradilan pidana ke proses di luar peradilan pidana. Dalam pelaksanaanya, diversi harus didasarkan pada pendekatan keadilan restoratif (restorative justice). Keadilan restoratif, menurut Pasal 1 angka 6 UU
${ }^{17}$ Ibid.
${ }^{18}$ Ibid. 
SPPA, dimaknai sebagai "proses penyelesaian perkara tindak pidana dengan melibatkan pelaku, korban, keluarga pelaku/korban, dan pihak lain yang terkait untuk bersama-sama mencari penyelesaian yang adil dengan menekankan pemulihan kembali pada keadaan semula, dan bukan pembalasan".

Dalam ketentuan Pasal 8 ayat (1) UU SPPA menyatakan bahwa, "proses diversi dilakukan melalui musyawarah dengan melibatkan Anak dan orangtua/ walinya, korban dan/atau orangtua/walinya, pembimbing kemasyarakatan, dan pekerja sosial profesional berdasarkan pendekatan keadilan restoratif". Dengan demikian, dalam suatu proses diversi atas suatu tindak pidana yang dilakukan anak, yang harus diperhatikan adalah kepentingan terbaik bagi anak. Dalam proses diversi, tidak boleh hanya melibatkan dari pihak pelaku/keluarga pelaku dan korban/keluarga korban saja, melainkan juga harus melibatkan beberapa pihak seperti pembimbing kemasyarakatan maupun pekerja sosial profesional. Dalam hal ini, melalui Jaringan Perlindungan Anak (JPA) yang digagas oleh aparat Kelurahan Kuningan, bekerja sama dengan stake holder terkait, berupaya untuk ikut andil dalam proses diversi terhadap anak dari wilayah Kelurahan Kuningan yang terjerat kasus hukum. Dengan demikian, upaya yang dilakukan oleh Kelurahan Kuningan sudah sejalan dengan ketentuan Pasal 8 ayat (1) UU SPPA.

Berdasarkan uraian-uraian di atas, wilayah ramah anak yang dibentuk di Kelurahan Kuningan, bisa menjadi wilayah yang benar-benar ramah bagi anak. Tidak hanya bagi anak-anak pada umumnya, menghindarkan anak menjadi korban tindak pidana, namun juga anak yang berhadapan dengan hukum. Perlu kami tekankan di sini, maksud pernyataan wilayah ramah anak bagi anak pelaku tindak pidana, bukan berarti wilayah Kuningan menjadi tempat yang menyenangkan/ "surga" bagi anak pelaku tindak pidana. Namun demikian harus dimaknai bahwa Kelurahan Kuningan siap melakukan segala upaya terbaik dalam proses hukum yang dihadapi warganya, sehingga kepentingan yang terbaik bagi anaklah yang harus diperhatikan.

\section{Kesimpulan}

1. Wilayah ramah anak di Kelurahan Kuningan menjadi project pertama dari Pemerintah Kota Semarang. Pembangunan wilayah ramah anak di Kelurahan Kuningan diawali dengan penataan dan pembangunan beberapa fasilitas umum seperti taman, pengecatan jalan dan kampung menggunakan warna "pelangi", pembuatan taman bacaan. Selain penataan dan pembangunan fasilitas umum, wilayah ramah anak di Kelurahan Kuningan juga melakukan pembangunan yang bersifat non fisik, seperti misalnya menyediakan bimbingan belajar bagi anak, memberikan latihan bela diri, menyelenggarakan car free day di wilayah Kelurahan Kuningan. Wilayah ramah anak di Kelurahan Kuningan pada dasarnya tidak dibentuk untuk mengurangi kriminalitas yang dilakukan anak. Sebelum pembentukan wilayah ramah anak, kelurahan Kuningan terkenal dengan kampung kumuh. Namun semenjak statusnya diubah menjadi wilayah ramah anak, stigma negatif dari Kelurahan Kuningan perlahan-lahan mulai hilang, diganti dengan citra yang positif.

2. Wilayah ramah anak yang dibentuk di Kelurahan Kuningan pada dasarnya tidak bisa menghilangkan keseluruhan kenakalan atau kriminalitas anak di wilayah Kuningan. Hal ini dikarenakan banyak faktor yang menyebabkan tidak bisa hilangnya kenakalan atau kriminalitas anak, yaitu faktor lingkungan dan kepedulian orangtua yang rendah terhadap perkembangan anaknya. Walaupun pembentukan wilayah ramah anak tidak menghilangkan keseluruhan kenakalan 
atau kriminalitas anak, namun pembentukan wilayah ramah anak di Kelurahan Kuningan, bisa meminimalisasi kenakalan atau kriminalitas anak. Dengan demikian, akan terbentuk generasi baru yang menjadi pemutus mata rantai kenalan atau kriminalitas yang dilakukan oleh generasi sebelumnya. Oleh karena itu, walaupun pembentukan wilayah ramah anak tidak ditujukan untuk menghilangkan angka kenakalan atau kriminalitas anak, namun program ini dapat dijadikan sebagai pemutus mata rantai kenakalan atau kriminalitas yang dilakukan anak, yaitu dengan membentuk sebuah generasi baru yang berperilaku sesuai dengan normanorma yang ada di masyarakat.

\section{E. Saran}

1. Sampai saat ini, wilayah ramah anak yang diterapkan di Kelurahan Kuningan, baru dilaksanakan di RW IX. Hal ini bisa menjadi kekurangan. Oleh karena itu, seyogianya pembentukan wilayah ramah anak harus dilaksanakan di setiap RW, tidak terfokus pada satu RW saja. Dengan demikian, secara keseluruhan, wilayah Kelurahan Kuningan dapat menjadi wilayah yang benar-benar ramah bagi anak. Bahkan tidak menutup kemungkinan apabila hal ini dapat dilakukan dengan maksimal, maka Kelurahan Kuningan dapat menjadi tempat wisata atau rujukan bagi daerah lain dalam pembentukan suatu wilayah yang ramah anak.
2. Adanya perhatian lebih yang diberikan orangtua terhadap perilaku anaknya. Hal ini dikarenakan, tanpa dukungan dari pihak orangtua, mustahil program wilayah ramah anak akan berjalan dengan maksimal. Dalam hal ini, peran orangtua sangat strategis dalam mencegah perilaku menyimpang atau bahkan kriminalitas yang dilakukan anak. Dengan demikian, diharapkan dapat dibentuk generasi-generasi baru yang jauh dari perilaku-perilaku negatif, seperti tawuran, mencuri, ngelem, menggunakan obat-obat terlarang.

\section{DAFTAR PUSTAKA}

Fajar, Mukti, dan Yulianto Achmad. Dualisme penelitian hukum normatif dan empiris. Yogjakarta: Pustaka Pelajar, 2010.

"Kelurahan Kuningan Semarang Utara Kini Jadi Kota Ramah Anak." Diakses 11 Maret 2018.

http://semarangkota.go.id/berita/read/7/b erita-kota/1665/kelurahan-kuningansemarang-utara-kini-jadi-kota-ramahanak.

"Rincian Data Kasus Berdasarkan Klaster Perlindungan Anak, 2011-2016 | Bank Data Perlindungan Anak." Diakses 11 Maret 2018. http://bankdata.kpai.go.id/tabulasidata/data-kasus-per-tahun/rincian-datakasus-berdasarkan-klaster-perlindungananak-2011-2016.

Soemitro, Ronny Hanitijo. Metode penelitian hukum dan jurimetri. Jakarta, Indonesia: Ghalia, 1990.

Sumarno, Joko, 23 November 2017. Trijanto, 28 November 2017. 